\title{
The Contextual Components of Ecotoxicology
}

\author{
John Cairns Jr* \\ Virginia Polytechnic Institute and State University, Blacksburg, VA, USA
}

DOI: 10.1897/1551-3793-5.3.349.b

*icairns@vt.edu

Thought processes are contextual, so humans assimilate new information and ideas best when they can be associated with familiar contexts. In graduate school I studied freshwater protozoans, and my first professional position (summer 1948) in the Department of Limnology at the Academy of Natural Sciences in Philadelphia required that I gather information on pollution effects in aquatic communities in the Conestoga River basin ecosystem. Two river survey teams studied everything from bacteria to fish, plus water chemistry. Sampling areas were both above and below point source water discharges so that effects upon aquatic life could be compared. Occasionally, both teams would sample the same area at different times during the same day so that variability (e.g., splitters vs lumpers) could be determined. In fall 1948, a single permanent river survey team was formed, and I continued studies of freshwater protozoan communities in North America and other parts of the world (e.g., headwaters of the Amazon River). Consequently, early in my career I viewed pollutional effects in a systems context.

Freshwater protozoan samples are highly perishable (also bacterial and water chemistry samples), but collections of algae, invertebrates, and fish could be preserved for later identification. As a result, I had more free time between surveys than most other team members and was selected by the Department of Limnology Head, Dr. Ruth Patrick, to carry out toxicity testing on bluegill sunfish. Dr. WB Hart, an advisor to the Department of Limnology, not only mentored me in toxicology but gave me the equipment used in the research that led to the publication of the monograph The Evaluation of the Toxicity of Industrial Wastes, Chemicals and Other Substances to Fresh Water Fishes (Hart et al. 1945). The toxicology context in 1949 was single species (first humans, then domesticated animals, then species of commercial/recreational value). So from the outset I attempted to place single species tests in an ecological context. Biological journals did not view my early manuscripts as "suitable," but engineering journals did. So I used their context for publishing research results.

My first tests using Hart's methodology were on industrial wastes, but in a few years I began research on individual chemical compounds and created mixtures. At times, the team surveyed a river before an industrial plant was completed, and I did toxicity tests on estimated waste composition. Once the industrial plant was operational, the team did studies to determine the effects, if any, of the actual waste discharges.

These toxicity tests were predictive (estimated damage), and the river surveys were reactive (identified damage after it occurred). Clearly, methodology for determining ecotoxicological effects in natural systems using attributes of ecosystems, such as nutrient and energy transfer, would have been desirable. Also badly needed were methodologies to determine the condition of natural capital, especially the delivery of ecosystem services upon which human survival depends. Similarly, laboratory systems (e.g., microcosms and mesocosms) must more closely resemble complex natural systems or the predictive models will not work well. In short, until ecotoxicology has robust predictive models for complex, multivariate ecosystems, it will not reach maturity.

In my opinion, the major obstacle to achieving this desirable state is contextual. This state will not be readily achieved by merely bringing scientists (e.g., ecology and toxicology) together. Such a gathering would be commendable, but time is short and solutions to global problems (e.g., toxics and climate change) require a multiplicity of contexts combined in one master global context. Developing this global context will not be easy since the 20th century was an age of specialization, thus the context for graduate students has been that of their major discipline. The rites of passage for each discipline (i.e., courses, prelims, finals, thesis, and dissertation structure) have reinforced the context in which students viewed the complex, natural world. This view is not 
always the best one. When the academic world had fewer individuals, the disciplines were far less isolated from each other. In fact, the famous academic British "eating clubs" and their counterparts in other countries often met weekly and comfortably had what would now be called transdisciplinary discussions.

These individuals were clearly transcontextual. If they existed when science was young, they can exist again. The global systems context is more daunting than the earlier contextual viewpoints, but the requirement is the same-multicontextual individuals. In summary, ecotoxicology has the potential to be vastly more contextual than it now is. The transition will not be automatic-it will only result from an organizational effort (e.g., SETAC). Synthesis will be impaired if the number of contexts is expanded too rapidly.

\section{REFERENCE}

Hart WB, Doudoroff P, Greenbank J. 1945. The Evaluation of the Toxicity of Industrial Wastes, Chemicals and Other Substances to Fresh Water Fishes. Philadelphia (PA): Waste Control Laboratory, Atlantic Refining. 